\title{
HER2/Neu Positive
}

National Cancer Institute

\section{Source}

National Cancer Institute. HER2/Neu Positive. NCI Thesaurus. Code C68748.

A laboratory test result indicating the presence of HER2/Neu in a tissue sample. 